\title{
"Mediating Effect of continuous improvements on management accounting innovations-information capital maturity level-organizational performance relationships"
}

Noorlailie Soewarno (D https://orcid.org/0000-0003-2134-2125

AUTHORS

R http://www.researcherid.com/rid/Q-2186-2018

Agus Widodo Mardijuwono (D) https://orcid.org/0000-0001-8000-9918

R http://www.researcherid.com/rid/Q-3327-2018

Noorlailie Soewarno and Agus Widodo Mardijuwono (2018). Mediating Effect of continuous improvements on management accounting innovations-information capital maturity level-organizational performance relationships. Problems and Perspectives in Management, 16(3), 356-365. doi:10.21511/ppm.16(3).2018.28

ARTICLE INFO http://dx.doi.org/10.21511/ppm.16(3).2018.28

DOI Wednesday, 05 September 2018

RELEASED ON Friday, 30 June 2017

RECEIVED ON Thursday, 19 April 2018

ACCEPTED ON

\section{(co) EY-NG}

LICENSE

This work is licensed under a Creative Commons Attribution-NonCommercial 4.0 International License

JOURNAL

"Problems and Perspectives in Management"

ISSN PRINT $1727-7051$

ISSN ONLINE $1810-5467$

PUBLISHER

LLC "Consulting Publishing Company "Business Perspectives"

FOUNDER

LLC "Consulting Publishing Company "Business Perspectives"

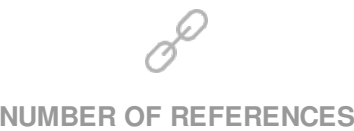

26
NUMBER OF FIGURES

2
NUMBER OF TABLES

7

(C) The author(s) 2022. This publication is an open access article. 


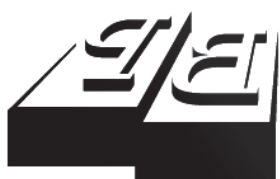

BUSINESS PERSPECTIVES

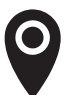

LLC "CPC "Business Perspectives" Hryhorii Skovoroda lane, 10, Sumy, 40022, Ukraine

www.businessperspectives.org

Received on: $30^{\text {th }}$ of June, 2017 Accepted on: $19^{\text {th }}$ of April, 2018

(C) Noorlailie Soewarno, Agus Widodo Mardijuwono, 2018

Noorlailie Soewarno, SE., MBA., CA., CMA., Assistant Professor of Accounting, Faculty of Economic and Business, Universitas Airlangga, Indonesia.

Agus Widodo Mardijuwono, Drs. MSi., Ak., CMA., Assistant Professor of Accounting, Faculty of Economic and Business, Universitas Airlangga, Indonesia.

\section{ORGANIZATIONAL PERFORMANCE RELATIONSHIPS}

\begin{abstract}
Performance is the primary focus of each company. Management is always expected to achieve excellent performance by stakeholders. Previous studies asserted that management accounting innovations and information capital maturity level are two important factors that support the success of business process performance. Therefore, this study empirically investigates two theoretical paths. Firstly, whether continuous improvements mediate management accounting innovations-organizational performance relationship. Secondly, whether continuous improvements mediate information capital maturity levelorganizational performance relationship. Using a sample of 54 managers of the Indonesian State-Owned Enterprises (SOEs), this study finds that continuous improvements fully mediate management accounting innovations-organizational performance relationship. Furthermore, this study also finds that continuous improvements do not mediate information capital maturity level-organizational performance relationship. Overall, this study gives empirical support for contingency theory, especially in providing contingent factors affecting organizational performance, namely management accounting innovations, information capital maturity level, and continuous improvements.
\end{abstract}

\section{Keywords}

management accounting innovations, information capital maturity level, continuous improvements, organizational performance

\section{JEL Classification L25}

\section{INTRODUCTION}

Performance is the primary focus of each company. It is the degree to which a feat is being or has been accomplished (Al-Refaie, 2015). Management is always expected to achieve excellent performance by stakeholders. In the era of global competition, this becomes a big challenge for management team. It goes without saying that companies need to investigate and apply a differentiated strategy versus others to stand out in the crowd (Azizi et al., 2009). Only company that has competitive advantage will be able to perform as expected. Sustainable competitive advantage can only be achieved by a company using right strategy and executing it effectively. Planning, coaching, and evaluation are critical elements of business strategy (Wheelen \& Hunger, 2012).

Organizational performance should express a comprehensive picture of performance that has both financial and non-financial perspectives, which offer knowledge on the degree of objectives and results achievement (Lebans \& Euske, 2006). The financial perspectives allude to the firm's benefit, incomes, cost reduction and profitability that are related, directly and indirectly, to the firm's relational strategy (Camarero, 
2007). Or in another words, the financial performance of a company is the result of non-financial performance, which includes customer operations, as well as learning and growth performance. Marketing performance is a critical determinant of financial performance, because it has direct contact with customers who buy products.

As a measure of customer satisfaction, employee morale, productivity, quality of output, and delivery performance (Abdullah et al., 2008), organizational performance is also the result of continuous business process improvements, which should always adapt to the changing dynamic business environment. Without continuous improvements in business processes, a company will be abandoned by their customers. Furthermore, superior performance in business processes is a reflection of organization's strategy.

Management accounting innovations and information capital maturity level are two important factors that support the success of business process performance. Zawawi and Hoque (2010) define management accounting innovations as the adoption of new management accounting system, for example, the application of Activity Based Costing (ABC), Activity Based Management (ABM), Time-Driven ABC, Target Costing, Balanced Scorecard, etc. It refers to the accounting creativity as one of the pillars of good corporate governance and it must be supported by a reliable information system infrastructure. Information capital maturity level refers to the degree of alignment between information capital readiness and business strategy.

This study aims to prove the contingency theory by focusing on the mediating impact of continuous improvement on management accounting innovations-information capital maturity level-organizational performance relationships. This study was conducted at the State-Owned Enterprises (SOEs) in Indonesia. The SOEs were chosen due to its strategic role in the Indonesian economy, apart from private sector and cooperatives.

This study contributes to the development of contingency theory by providing contingency factors affecting organizational performance in a more comprehensive research model. In addition to the contingency theory, it also investigates the support for the Resource-Based View (RBV) theory, which states that competitive advantage and organizational performance are affected by factors internal to organization, especially assets, skills, and capabilities. The contingency theory provides an explanation that there are no factors that "fit" for all circumstances, and performance of an organization depends on a variety of contingent factors. Therefore, this study raises two main issues. First issue is whether continuous improvements mediate management accounting innovations-organizational performance relationship. Second issue is whether continuous improvement mediates management information capital maturity level-organizational performance relationship?

\section{LITERATURE REVIEW AND HYPOTHESES DEVELOPMENT}

\subsection{Management accounting innovations, continuous improvements, and organizational performance}

Traditionally, performance in organization has been measured by using financial indicators such as profit, market share, earnings and growth rate. However, non-financial indicators also must be considered in accessing performance (Osman et al., 2016). According to Kaplan and Norton (2004), organizational performance includes both financial performance and non-financial performance, such as customer operations, as well as learning and growth. Financial performance is the end result to be achieved by every company, which generally can be seen from company's profitability. Kaplan and Norton (2002) state that financial performance can consist of revenue growth, asset utilization, cost structure, and customer value. As a result, financial performance is driven by customer performance, business processes performance, as well as learning and growth performance. 
In the conditions of intense competition, gaining a large market share, dominating market, and winning competition are very important for companies to achieve revenue and profitability growth. Marketing performance will be achieved when company can satisfy customer needs (Mone et al., 2013). Customer management processes, which determine customer performance as proposed in Kaplan and Norton (2004), include: (1) customer selection as the ability to select attractive customer segments, offering value on customer groups, and building brand image for group of customers that are interested in company's products; (2) customer acquisition as how to communicate to market, getting leads, and turn prospects into customers; (3) customer retention as how to guarantee product quality and to transform to be satisfied and loyal customers; (4) customer growth as to understand customers more deeply and increase share of customer purchases to company. The ultimate outcome of customer performance is customer satisfaction in term of product attributes, relationship, and image. Customer performance reflects value proposition to customers.

Continuous improvements can be defined as the planned, organized, and systematic process of ongoing, incremental, and company-wide change of existing practices aimed at achieving the performance improvement (Boer et al., 2000; Kaplan \& Norton, 2004; Ali et al., 2012). In their study, Oprime and Mendez (2012) conclude that: (1) the success of continuous improvements in a company depends on training on tools to solve problem, incentives for proposals and ideas that have impact on improvements, face-to-face communication, and a visit to shop floor, and (2) continuous improvements contribute on increasing productivity, quality, lead time, cost efficiency, customer satisfaction, and establishment of workers' skills to solve problems. Continuous improvements will have a positive impact on internal business processes performance, including production, cost efficiencies, quality, timeliness and accuracy of delivery of goods and services to customers. Those will improve customer performance and finally increase financial performance. In summary, continuous improvements will improve organizational performance. Continuous improvements and significant positive effect on financial performance can be measured by an increase in return on investment (Heavy et al., 2014).
Kaplan and Norton (2004) have proposed a new performance management system called the Balanced Scorecard (BSC), which becomes one of the key findings in management accounting innovations. It provides a tool for executing strategy and aligning daily operational activities of company to strategy. It becomes easier for a company to achieve vision and mission. Ultimate outcome of value creation is financial performance, especially long-term shareholder value. Dabhilkar and Bengtsson (2002) stated that in brief, BSC is a multidimensional approach to performance measurement and management control, which is linked specifically to organizational strategy.

In a very dynamic business environment, knowledge becomes very important for a company to deliver innovative value to customers and to survive in industry. Innovations can boost service differentiation; hence, it is important for managers to put into action these innovations, which are wanted by the people to yield earnings for the organization (Arshad et al., 2016). Walker et al. (2010) also asserted that innovation activities not only can increase efficiencies, but also can improve the administrative process, hence, more effective management. Achieving higher innovation performance requires organizations to harness the knowledge, skills, abilities, opportunities and willingness of employees to innovate. Human resources are a key factor in organizational innovation (Fu et al., 2015). Therefore, the role of management accounting is not just limited to traditional roles, such as planning and budgeting, but it has shifted toward how to link strategy with execution, internal decision making, improving performance, measuring, and managing factors that affect shareholder value (AICPA, 1998). The management accountants play an important role in increasing the adoption of management accounting innovations to achieve company's objectives using strategy (Yang et al., 2006; Clinton \& White, 2012).

Management accounting innovations improve accuracy in product pricing, enable better control of operations, improve efficiency, increase customer satisfaction, which, ultimately, can increase profitability (Chenhall \& Smith, 1999). From previous theoretical justification, the first hypothesis can be stated as follows: 
H1: Continuous improvements mediate management accounting innovations-organizational performance relationship.

\subsection{Information capital maturity level, continuous improvements, and organizational performance}

In the information age, information capital is the backbone of every company to maintain its competitive advantage and win the competition. Kaplan and Norton (2004) state that information capital, consisting of systems, databases, libraries, and networks, makes information and knowledge available to the organization. As presented in Table 1, information capital can be categorized into:

Table 1. Information capital category

Source: Kaplan and Norton (2004).

\begin{tabular}{|c|c|}
\hline $\begin{array}{l}\text { Information } \\
\text { capital } \\
\text { category }\end{array}$ & Description \\
\hline $\begin{array}{l}\text { Transformational } \\
\text { application }\end{array}$ & $\begin{array}{l}\text { Systems and networks that change } \\
\text { the prevailing business model of the } \\
\text { enterprise }\end{array}$ \\
\hline $\begin{array}{l}\text { Analytic } \\
\text { applications }\end{array}$ & $\begin{array}{l}\text { Systems and networks that promote } \\
\text { analysis, interpretation, and sharing of } \\
\text { information knowledge }\end{array}$ \\
\hline $\begin{array}{l}\text { Technology } \\
\text { infrastructure }\end{array}$ & $\begin{array}{l}\text { The shared technology and managerial } \\
\text { expertise required to enable effective } \\
\text { delivery and use of information Capital } \\
\text { Applications }\end{array}$ \\
\hline $\begin{array}{l}\text { Transaction } \\
\text { processing } \\
\text { applications }\end{array}$ & $\begin{array}{l}\text { Systems that automate the basic repetitive } \\
\text { transactions of the enterprise }\end{array}$ \\
\hline
\end{tabular}

Information capital is intangible in nature and it becomes the basis of competition in the information era. Therefore, information capital should be aligned with strategy. Henderson and Venkatraman (1993) state that strategic alignment model must have two dimensions as follows: (1) strategic integration involving the alignment between business strategy and IT strategy. So, it is widely accepted that aligning information capital to business strategies is important for achieving high performance; (2) functional integration involving the relationship between information capital and business units.
Organizational performance depends heavily on the ability to build strategic fit between strategy and proper structure of information technology to support strategy in order to win the competition (Ursacescu, 2014). Furthermore, Kaplan and Norton (2004) also state that information capital has value to an organization in the context of its strategy, which means the readiness of information capital to support the success of internal business processes, such as driving continuous improvements, enabling management to create products, matching or even surpassing customer expectations in a more efficient way. In summary, the higher the degree of alignment between information capital and strategy (information capital maturity level), the higher the opportunities to conduct continuous improvements, and, finally, the higher the achievement of financial performance. From the previous theoretical justification, the second hypothesis of this study can be stated as follows:

H2: Continuous improvements mediate capital information maturity level-organizational performance relationship.

\section{METHODS}

\subsection{Research setting and sample}

This study was designed as a quantitative research. As a quantitative research, this study aims to empirically test: (1) whether continuous improvements mediate management accounting innovations-organizational performance relationship; and (2) whether continuous improvement mediates information capital maturity level-organizational performance relationship. The population of this study is 119 Indonesian State-Owned Enterprises (SOEs). Since the number of SOEs is limited, the questionnaires were sent to all SOEs by email. One $\mathrm{SOE}$ was represented by one manager. As many as 54 managers participated in this study, or 45 percent response rate.

\subsection{Instruments}

\subsubsection{Organizational performance}

Organizational performance is performance of the SOEs perceived by each manager. It includes 
financial and non-financial performance, such as customer performance, operational performance, as well as learning and growth performance. This variable is measured by indicators developed as in Kaplan and Norton (2004) using a Likert scale of 1 to 6 ranging from "strongly disagree" to "strongly agree".

\subsubsection{Continuous improvements}

Continuous improvement is management's efforts perceived by each manager to improve business processes, particularly those related to operations management processes, customer management processes, innovation management processes, as well as social and regulatory processes. It is measured by indicators proposed as in Kaplan and Norton (2004) using a Likert scale between 1 and 6 ranging from "strongly disagree" to "strongly agree".

\subsubsection{Management accounting innovations}

Management accounting innovation is the use of contemporary management accounting techniques and methods perceived by each manager, such as the use of cost management, ActivityBased Costing, Balanced Scorecard. It is measured using a Likert scale of 1 to 6 ranging from "strongly disagree" to "strongly agree".

\subsubsection{Information capital maturity level}

Information capital maturity level is the degree of alignment between information capital readiness and business strategy perceived by each manager. It is a definite evolutionary table of process improvement (Tugas, 2010). It includes system, database, infrastructure, and Information and Communication Technology (ICT). It is measured using a Likert scale of 1 to 6 ranging from "strongly disagree" to "strongly agree".

This study used variance-based Structural Equation Modelling (SEM), because it can statistically solve the model simultaneously. Data were processed using the WarpPLS 5.0. It is considered more appropriate to use partial least square method for social studies that demand flexibility in assumptions.

\section{RESEARCH MODEL}

Referring to the previous background and theoretical overview, the research model can be described in Figure 1 as follows:

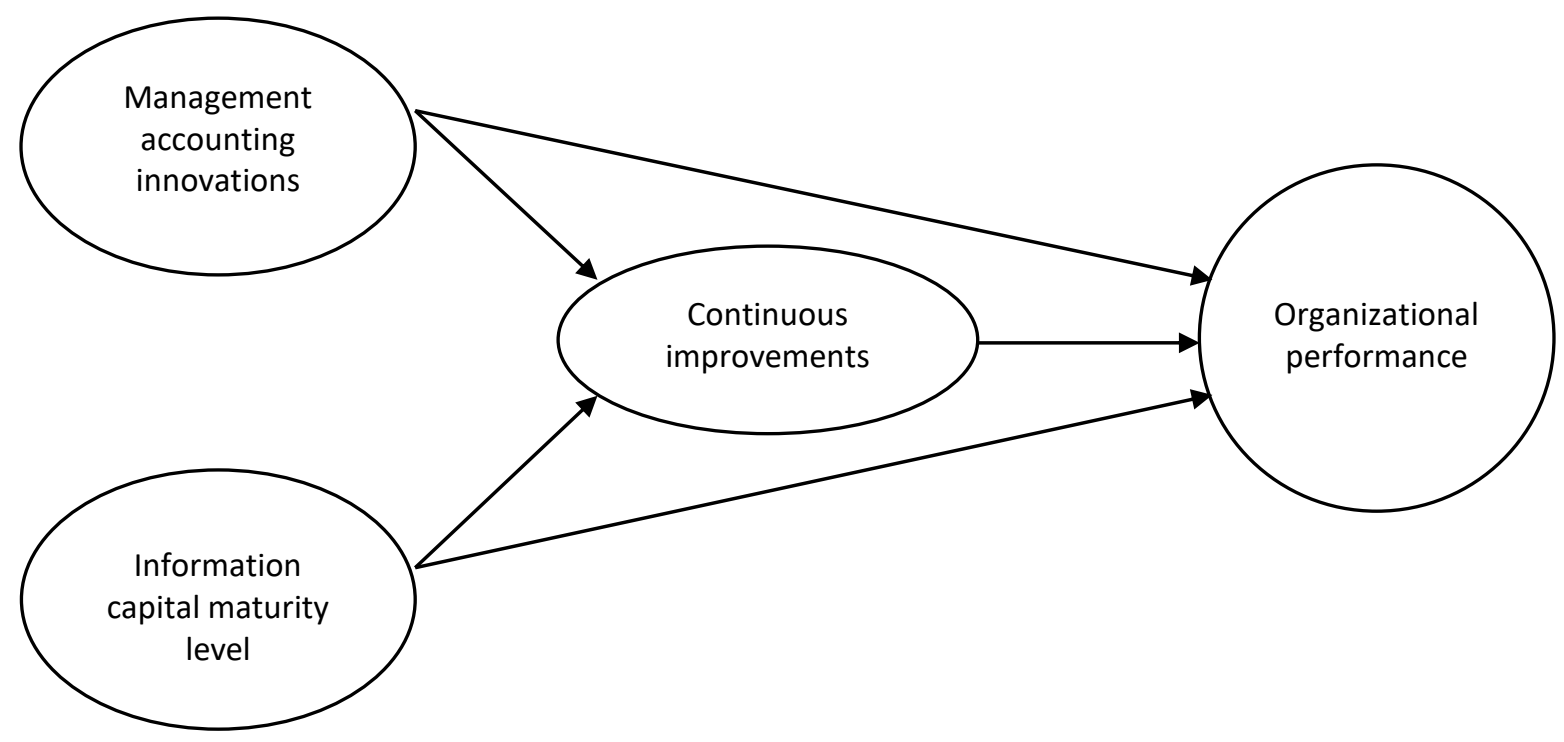

Figure 1. Research model 


\section{RESULTS AND DISCUSSIONS}

\section{A. DESCRIPTIVE STATISTICS OF VARIABLES}

Table 2 presents the descriptive statistics of variable studied, including theoretical and actual score (maximum and minimum values), mean and standard deviation. The results suggest that the sampled managers reported tendencies of better organizational performance (4.74) and the higher level of importance of continuous improvements (4.73). They also reported tendencies of the higher level of importance of information maturity level (4.32) and management accounting innovations (4.37).

Table 2. Descriptive statistics of variables

\begin{tabular}{|c|c|c|c|c|c|c|}
\hline \multirow{2}{*}{ Variable } & \multicolumn{2}{|c|}{$\begin{array}{c}\text { Theoretical } \\
\text { score }\end{array}$} & \multicolumn{2}{|c|}{ Actual score } & \multirow{2}{*}{ Mean } & \multirow[t]{2}{*}{ SD } \\
\hline & Min & Max & Min & Max & & \\
\hline $\begin{array}{l}\text { Information } \\
\text { Capital Maturity } \\
\text { Level (ICML) }\end{array}$ & 1 & 6 & 2 & 6 & 4.32 & 1.13 \\
\hline $\begin{array}{l}\text { Management } \\
\text { Accounting } \\
\text { Innovations } \\
(\mathrm{MAI})\end{array}$ & 1 & 6 & 2 & 6 & 4.37 & 0.96 \\
\hline $\begin{array}{l}\text { Continuous } \\
\text { Improvements } \\
(\mathrm{CI})\end{array}$ & 1 & 6 & 2.6 & 6 & 4.73 & 0.68 \\
\hline $\begin{array}{l}\text { Organizational } \\
\text { Performance } \\
(\mathrm{OP})\end{array}$ & 1 & 6 & 3 & 6 & 4.74 & 0.72 \\
\hline
\end{tabular}

\section{B. MEASUREMENT MODEL ANALYSIS}

To evaluate the relationship between measures and constructs, we use measurement model by assessing reliability and convergent validity. Table 3 presents that all measurements are significant ( $p$-value less than 0.001). Loading level more than 0.60 indicates that the measure is accounting for more than 60 percent of the variance of the underlying latent variable (Chin, 1998). Furthermore, the composite reliability coefficients of the constructs are above the accepted level of 0.70 (Nunnaly, 1967). This supports the reliability of measurement model. We use convergent validity and discriminant validity to assess construct validity. The AVE (Average Variance Extracted) of 0.50 or more is used to judge the convergent validity (Hulland, 1999). As shown in Table 3, this study reveals that all AVEs are above 0.50 indicating that the meas- urement model has adequate convergent validity. Table 4 also shows that all values of Average Variance Extracted (AVE), Cronbach's alpha, and composite reliability are more than 0.50 .

To evaluate discriminant validity, we compare the square roots of AVEs to the correlation between constructs. Discriminant validity indicates whether a construct shares more variance with its measures than with other constructs. It supports discriminant validity when the square root of AVE of a construct is greater than the correlation between the construct with another construct. Table 5 shows that the diagonal elements are greater than their respective off-diagonal elements. This indicates a support for discriminant validity. In conclusion, the evaluation shows that the measurement model is reliable and valid.

Table 3. Reliability and convergent validity

\begin{tabular}{|c|c|c|}
\hline Latent variable & Loading & P-value \\
\hline \multicolumn{3}{|c|}{ ICML (Composite reliability $=0.960 ;$ AVE $=0.857$} \\
\hline ICML 1 & 0.921 & $<0.001$ \\
\hline ICML 2 & 0.927 & $<0.001$ \\
\hline ICML 3 & 0.925 & $<0.001$ \\
\hline $\mathrm{ICML} 4$ & 0.93 & $<0.001$ \\
\hline \multicolumn{3}{|c|}{ MAI (Composite reliability $=0.954 ;$ AVE $=0.805$} \\
\hline MAI 1 & 0.847 & $<0.001$ \\
\hline MAI 2 & 0.917 & $<0.001$ \\
\hline MAI 3 & 0.942 & $<0.001$ \\
\hline $\mathrm{MAI} 4$ & 0.893 & $<0.001$ \\
\hline MAI 5 & 0.883 & $<0.001$ \\
\hline \multicolumn{3}{|c|}{$\mathrm{CI}($ Composite reliability $=0.925 ;$ AVE $=0.712$} \\
\hline $\mathrm{Cl} 1$ & 0.876 & $<0.001$ \\
\hline $\mathrm{Cl} 2$ & 0.866 & $<0.001$ \\
\hline $\mathrm{Cl} 3$ & 0.797 & $<0.001$ \\
\hline $\mathrm{Cl} 4$ & 0.844 & $<0.001$ \\
\hline $\mathrm{Cl} 5$ & 0.835 & $<0.001$ \\
\hline \multicolumn{3}{|c|}{ OP $($ Composite reliability $=0.948:$ AVE $=0.819$} \\
\hline OP 1 & 0.895 & $<0.001$ \\
\hline OP 2 & 0.913 & $<0.001$ \\
\hline OP 3 & 0.936 & $<0.001$ \\
\hline OP 4 & 0.874 & $<0.001$ \\
\hline
\end{tabular}

Table 4. Latent variable coefficients

\begin{tabular}{|c|c|c|c|c|}
\hline Description & ICML & MAI & $\mathrm{CI}$ & OP \\
\hline R-squared & - & - & 0.37 & 0.766 \\
\hline Composite reliability & 0.96 & 0.954 & 0.925 & 0.948 \\
\hline Cronbach's alpha & 0.944 & 0.926 & 0.899 & 0.926 \\
\hline $\begin{array}{l}\text { Average variance } \\
\text { extracted }\end{array}$ & 0.857 & 0.805 & 0.712 & 0.819 \\
\hline Full collin. VIF & 2.94 & 2.758 & 2.316 & 2.634 \\
\hline Q-squared & - & - & 0.374 & 0.64 \\
\hline
\end{tabular}


Table 5. Discriminant validity

\begin{tabular}{l|c|c|c|c}
\hline Variable & ICML & MAI & CI & OP \\
\hline ICML & 0.926 & 0.768 & 0.515 & 0.644 \\
\hdashline MAI & 0.768 & 0.897 & 0.58 & 0.565 \\
\hdashline $\mathrm{Cl}$ & 0.515 & 0.58 & 0.844 & 0.719 \\
\hdashline OP & 0.644 & 0.565 & 0.719 & 0.905 \\
\hline
\end{tabular}

\section{STRUCTURAL MODEL ANALYSIS}

\section{1) Direct effect}

Table 6. Direct effect

\begin{tabular}{c|c|c|c}
\hline $\begin{array}{c}\text { Direct } \\
\text { Effect }\end{array}$ & $\begin{array}{c}\boldsymbol{\beta} \\
\text { coefficient }\end{array}$ & Probability & $\begin{array}{c}\mathbf{R}^{2} \text { coefficient of } \\
\text { determination }\end{array}$ \\
\hline $\mathrm{MAI}>\mathrm{OP}$ & 0.57 & $\mathrm{P}<0.01$ & 0.32 \\
\hline $\mathrm{ICML}>\mathrm{OP}$ & 0.68 & $\mathrm{P}<0.01$ & 0.46 \\
\hline
\end{tabular}

Table 6 shows that the direct effect of management accounting innovations (MAI) on organizational performance (OP) has a $\beta$ coefficient of 0.57 with $p$-value less than 0.01 . It means that management accounting innovations positively and significantly affect organizational performance. The coefficient of determination of 0.32 demonstrates that $32 \%$ of the variability in management accounting innovations can explain the variability in organizational performance. Furthermore, the direct effect of information capital maturity level (ICML) on organizational performance (OP) has a $\beta$ coefficient of 0.68 with $p$-value less than 0.01 . It means that information capital maturity level positively and significantly affects organizational performance. The coefficient of determination of 0.48 demonstrates that $48 \%$ of the variability in information capital maturity level can explain the variability in organizational performance.

\section{2) Direct and indirect effect with mediating variable of continuous improvements}

Table 7 shows the results of full model. The direct effect of management accounting innovations (MAI) on organizational performance (OP) has a $\beta$ coefficient of 0.11 (decreasing value from the old $\beta$ value of 0.57 without mediating variable of continuous improvements $(\mathrm{CI})$ and it has insignificant $p$-value of 0.20 . This indicates that continuous improvement fully mediates management accounting innovations-organiza- tional performance relationship. Table 7 also reveals that management accounting innovations also has a direct effect on continuous improvements with a $\beta$ value of 12.44 and $p$-value less than 0.01 . It shows that continuous improvements has a direct effect on organizational performance with a $\beta$ value of 0.56 and $p$-value less than 0.01 . In summary, management accounting innovations have a direct effect on continuous improvements, and continuous improvements have a direct effect on organizational performance. Total indirect effect of management accounting innovations on organizational performance through continuous improvements is 0.244 with $p$-value of 0.004 , which is less than 0.05. This indicates that hypothesis 1 stating continuous improvements mediate management accounting innovations-organizational performance relationship is supported. This results support previous studies conducted as in Kaplan and Norton (2004), Oprime and Mendez (2012), and Heavy et al. (2014) stating that continuous improvement is a critical factor for company to survive and grow in competitive and dynamic business environment. Company needs to improve continuosly in term of operations management, customer management, innovation management, regulatory management processes.

The direct effect of information capital maturity level (ICML) on organizational performance (OP) has a $\beta$ coefficient of 0.42 (decreasing value from the old $\beta$ value of 0.68 without mediating variable of continuous improvements (CI) and it has insignificant $p$-value less than 0.01 . However, $p$-value of the effect of information capital maturity level on continuous improvements is not smaller than 0.05. In addition, the indirect effect of information capital maturity level on organizational performance through continuous improvements is 0.117 with $p$-value of 0.103 , which is bigger than 0.05 . This indicates that hypothesis 2 stating continuous improvements mediate capital information maturity level-organizational performance relationship is not supported. This result implies that according to sampled managers, the alignment of information capital and business strategy in the SOEs is not quite ready (the lowest mean value of 4.32 in descriptive statistics compared to other constructs) to support continuous improve- 


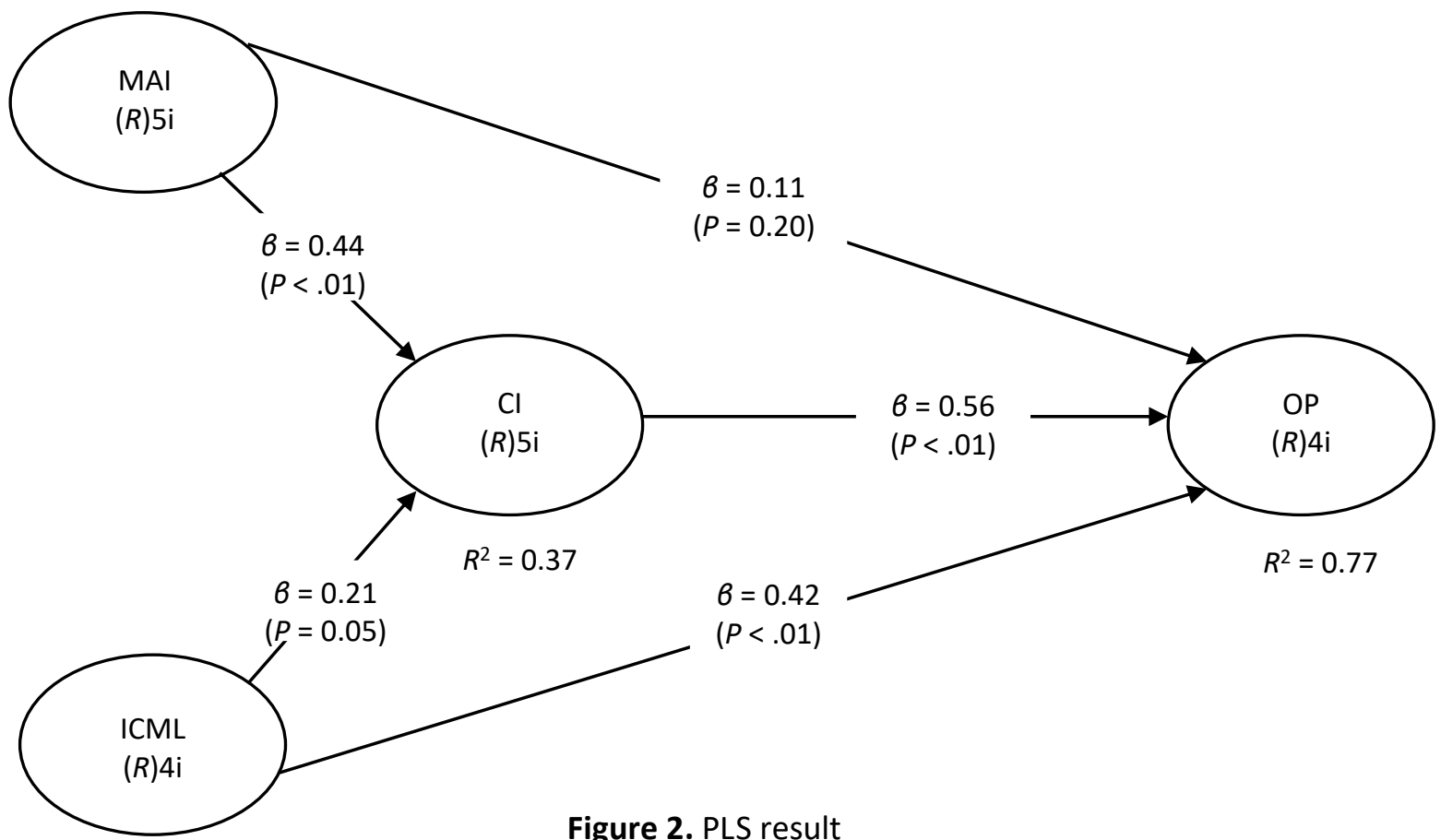

ments. In addition, Heavy et al. (2014) state that forces of continuous improvements are customer value, strategic objectives, improvements specialists, knowledge, and improvements methodology. Therefore, continuous improvements cannot immediately mediate information capital maturity level-organizational performance relationship.

Table 7. Direct and indirect effect evaluation with continuous improvements as mediating variable

\begin{tabular}{|c|c|c|c|}
\hline Description & $\begin{array}{c}\beta \\
\text { coefficient }\end{array}$ & Probability & $\begin{array}{l}\mathbf{R}^{2} \text { coefficient of } \\
\text { determination }\end{array}$ \\
\hline \multicolumn{4}{|c|}{ After inserting intervening varible: } \\
\hline \multicolumn{4}{|c|}{ Direct effect: } \\
\hline $\mathrm{MAI}>\mathrm{OP}$ & 0.11 & $P=0.20$ & 0.77 \\
\hline $\mathrm{ICML}>\mathrm{OP}$ & 0.42 & $\mathrm{P}<0.01$ & 0.77 \\
\hline $\mathrm{Cl}>\mathrm{OP}$ & 0.56 & $P<0.01$ & 0.77 \\
\hline $\mathrm{MAI}>\mathrm{Cl}$ & 0.44 & $P<0.01$ & 0.37 \\
\hline $\mathrm{ICML}>\mathrm{Cl}$ & 0.21 & - & 0.37 \\
\hline Description & $\begin{array}{c}\text { Indirect } \\
\text { effect }\end{array}$ & Probability & Decision \\
\hline \multicolumn{4}{|c|}{ Indirect effect } \\
\hline MAI-Cl-OP & 0.244 & 0.004 & $\mathrm{H} 1$ is accepted \\
\hline ICML-CI-OP & 0.117 & 0.103 & $\begin{array}{l}\mathrm{H} 2 \text { is not } \\
\text { accepted }\end{array}$ \\
\hline
\end{tabular}

Table 8. Model fit and quality indices

\section{Model fit and quality indices}

Average path coefficient $(\mathrm{APC})=0.348, \mathrm{P}=0.001$

Average R-squared $(\mathrm{ARS})=0.568, \mathrm{P}<0.001$

Average adjusted R-squared $(\mathrm{AARS})=0.549, \mathrm{P}<0.001$

Average block VIF $(\mathrm{AVIF})=2.290$, acceptable if $<=5$, ideally $<=3.3$

Average full collinearity VIF $(\mathrm{AFVIF})=2.662$, acceptable if $<=5$, ideally $<=3.3$

Tenenhaus GoF $(\mathrm{GoF})=0.674$, small $>=0.1$, medium $>=0.25$, large $>=0.36$

Sympson's paradox ratio $(S P R)=1.000$, acceptable if $>=0.7$, ideally $=1$

R-squared contribution ratio $($ RSCR $)=1.000$, acceptable if $>=0.9$, ideally $=1$

Statistical suppression ratio $(S S R)=1.000$, acceptable if $>=0.7$

Nonlinear bivariate causality direction ratio

$($ NLBCDR $)=1.000$, acceptable if $>=0.7$

Table 8 shows the model fit and quality indices. It reveals that the model is fit based on all values of APC, ARS, and AARS of less than 0.05. Meanwhile, the values of AVIF and AFVIF are 2.290 and 2.662 , respectively, which is less than ideal value of 3.3 . 


\section{CONCLUSION, LIMITATION AND FUTURE RESEARCH}

From previous discussions, it could be concluded that: 1) continuous improvements fully mediate management accounting innovations-organizational performance relationship. Company needs to improve continuosly in terms of operations management, customer management, innovation management, regulatory management processes; 2) continuous improvements do not mediate information capital maturity level-organizational performance relationship. The alignment of information capital and business strategy in the SOEs is not quite ready. In addition, forces of continuous improvements are customer value, strategic objectives, improvements specialists, knowledge, and improvements methodology. This study only involves the sample of 54 managers. This small sample may bring the limitation toward its predictive power. Future research could be done using more sample, and using more industr sector and not limited to only the state-owned company.

\section{REFERENCES}

1. Abdullah, M. M., Uli, J., \& Tari, J. J. (2008). The Influence of Soft Factors on Quality Improvement and Performance. The TQM Journal, 20(5), 436-452.

2. AICPA. American Institute of CPAs (1998). The CPA Vision Project: 2011 and Beyond.

3. Ali, J. A. et al. (2012). A Study of Sustainability of Continuous Improvement in The Manufacturing Industries in Malaysia. Management of Environmental Quality: An International Journal, 24(3), 408-426.

4. Al-Refaie, A., \& Al-Tahat, M. D. (2015). Effects of Knowledge Management and Organizational Learning on Firm Performance. Journal of Nature Science and Sustainable Technology, 8(3).

5. Arshad, A. M., Wang, Jie, \& $\mathrm{Su}$, Qin (2016). Investigating The Mediating Role of Service Innovation in Firm Performance: An Empirical Research. The Journal of Applied Business Research, 32(2).

6. Azizi, S., Movahed, S. A., \& Khah, M. H. (2009). The Effect of Marketing Stratefy and Marketing Capability on Business performance. Case Study: Iran's Medial Equipment Sector. Journal of Medical Marketing, 9(4), 309-317. Retrieved from https://journals. sagepub.com/action/captchaChalle nge?redirectUri=\%2Fdoi $\% 2 \mathrm{Fpdf} \% 2$ F10.1057\%2Fjmm.2009.33

7. Boer, H., A., Berger, R. C., \& Gertsen, F. (2000). CI
Changes: From Suggestion Box to Organizational Learning. Continuous Improvements in Europe and Australia. Ash Gate Publishing, Aldershot.

8. Camarero, C. (2007). Relationship Orientation or Service Quality? The International Journal of Bank Marketing, 25(6), 406426. Retrieved from https:// www.researchgate.net/ publication/235310153_Relationship_Orientation_or_ Service_Quality_What_Is_the Trigger_of_Performance_in_Financial_and_Insurance_Services

9. Chenhall, R., \& Smith, K. L. (1999). Innovation in management accounting. Australian CPA, Sept, 69(8), 76-78.

10. Clinton, B. D., \& White, L. R. (2012). The Role of Management Accountant: 2003-2012. Management Accounting Quarterly, Fall, 14(1), 44-74. Retrieved from https://www.imanet.org/-/media/ 104eed2f3f3b4713a5f47e64f3121 92b.ashx

11. Dabhilkar, M., \& Bengtsson, Lars (2002). Balanced Scorecards for a Strategic and Sustainability Continuous Improvement Capability. Proceedings of CINet Conference, September. Espoo, Finland. Retrieved from https:// www.hig.se/download/18.4a72647 f12120571ab080001106/Dabhilkar \%26Bengtsson020612huvud.pdf

12. Fu, N. et al. (2015). How Do High Performance Work Systems
Influence Organizational Innovation in Professional Service Firms? Employee Relations, 37(2), 209-231.

13. Heavy, C., Ledwith, A., \& Murphy, E. (2014). Introducing a New Continuous Improvement Framework for Increased Return on Investmen. The Total Quality Management Journal, 26(6), 594-609.

14. Henderson, J., \& Venkatraman, N. (1999). Strategic Alignment: leveraging information technology for transforming organizations. IBM Systems Journal, 38(2.3), 472 484. Retrieved from https://ieeexplore.ieee.org/document/5387096/

15. Kaplan, R. S., \& Norton, D. P. (2002). The Balanced Scorecard. Boston MA: Harvard Business School Press. Retrieved from https://www.hbs.edu/faculty/ Pages/item. aspx? num $=8831$

16. Kaplan, R. S., \& Norton, D. P. (2004). Strategy Maps: Converting Intangible Assets into Tangible Outcomes. Boston MA: Harvard Business School Press.

17. Lebans, M., \& Euske, K. (2006) A Conceptual And Operational Delineation of Performance. Business Performance Measurement. Cambridge University Press.

18. Mone, S. D., Pop., M. D., \& Paina, N. D. R. (2013). The "What" and "How" of Marketing Performance Management. Management and Marketing Challenges for the Knowledge Society, 8(1), 129-146. 
19. Oprime, P.C., Mendez, G.H., \& Pimenta, M.L. (2012). Continuus improvement: Critical factors in Brazilian industrial companies. International Journal of Productivity and Perfomance Management, 61(1), 69-92.

20. Osman, Suriati., Shariff, S. H., \& Lajin, M. N. A. (2016). Does Innovation Contribute To Employee Performance? Procedia Social and Behavioral Sciences, 219, 571-579.

21. Tugas, F. C. (2010). Assessing The Level of Information Technology (IT) Processes Performance and Capability Maturity in The Philippine Food, Beverage, and Tobacco (FBT) Industry Using The COBIT Framework. Academy of Information and Management Sciences Journal, 13(1).

22. Ursacescu, M. (2014). Assessing The Maturity Level of Information Technology Management Process In A Romanian Company. International Journal of Management \& Information Systems. Third Quarter, 18(3), 201-212.

23. Walker, R. M., Damanpour, F., \& Deveece, C. A. (2010) Management Innovation and Organizational Performance: The Mediating Effect of Performance Management. Journal of Public Administration Research and Theory, 21(2), 367386. Retrieved from https://pdfs. semanticscholar.org/b60d/73d 3 16a76d9b439761f0357bd7b0f9d 85a33.pdf
24. Wheelen, T. L., \& Hunger, J. D. (2012). Strategic ManagementBusiness Policy (13th ed.). USA, Pearson.

25. Yang, H. L, Gra, G. Ll., Yang, W. W. (2006). Employee Demography Moderate Involvement of Decison Making and Adoption of Management Accounting Innovations for Chinesse Accountants. Journal of American Academy of Business, Sept. 9(2), 338-343.

26. Zawawi, N. H. M., \& Hoque, Z. (2010). Research in Management Accounting Innovations An Overview of Its Recent Development. Qualitative Research in Accounting \& Management, 7(4), 505-568 